\title{
Strategies for Solving World Food Crisis: Lessons, Constraints and Opportunities for Nigeria
}

\author{
T. O. Fadiji and D. F. Omokore \\ Institute for Agricultural Research (I.A.R.), \\ Faculty of Agriculture (FOA), Samaru \\ Ahmadu Bello University (A. B. U.), \\ P. M. B. 1044, Zaria, Nigeria. \\ Mobile: +2348035051898
}

\begin{abstract}
The two-sided economic down-turn and food crisis being experienced in many parts of the world has become a concern of many world leaders and peoples. The Malthusian theory is gradually steering many pessimists in the face as food production is nothing to compare with the population growth in many parts of the world. While poverty, insecurity and diseases pandemics are manifested in many facets of human life, food crisis is compounding the situation. The well-articulated Millennium Development Goals (MDGs) is almost half its deadline (2015) but the battle for control of severe poverty and deprivation is far from being won. Some notable factors responsible for food crisis are noted. Empirical examples of countries suffering from the problem of food insecurity and the repercussions on the national life are examined. Over many years now, different kinds of strategies have been employed to improve agricultural production in many countries of the world. Some recent approaches/strategies employed toward containing food crisis are reviewed and suggestions put forward for consideration. This paper presents a position, tracing the issues that contribute to food crisis, some strategies toward alleviating them and using Nigeria as a focal point. For, food security can only be assured if only majority of the people of the world are given that status.
\end{abstract}

Key words: World food crisis, agricultural development, lessons for Nigeria.

\section{Introduction}

The adage: "An hungry man is an angry man" is readily applicable to the situation in many parts of the world. Thomas Malthus, in his book: "An Essay on the Principle of Population as it Affects the Future Improvement of Society" (written in 1798) had once predicted that a world that is continually increasing in population without corresponding increase in food supply will be at jeopardy. At a stage, or for some time and due to abundance supply of food and increase in agricultural production in some countries, it appeared Malthus was wrong, but the warnings he gave had been of tremendous value in facilitating that development. Our world today seems to be fulfilling this prophecy. The population of the world in 2004, is put at 6.4 billion (UNDP, 2006). The indication from Table 1 depicts the world that is reproductively growing without being productive agriculturally.

"Food security refers to the availability of food and one's access to it. A household is considered food secure when its occupants do not live in hunger....." (Source: www.en.wikipedia.org/wiki/Food security/). 
Table 1: Breakdown of population (in millions) of regions of the world, 2005

\begin{tabular}{lccc}
\hline & \multicolumn{3}{c}{ Total population (in millions) } \\
& $\mathbf{1 9 7 5}$ & $\mathbf{2 0 0 4}$ & $\mathbf{2 0 1 5}$ \\
& & & (estimated) \\
\hline Developing countries & $2,967.1$ & $5,093.6$ & $5,885.6$ \\
Least developed countries & 355.2 & 740.7 & 950.1 \\
Arab States & 144.6 & 310.5 & 386.0 \\
East Asia and the Pacific & $1,310.4$ & $1,944.0$ & $2,108.9$ \\
Latin America and the Caribbean & 318.4 & 548.3 & 628.3 \\
South Asia & 838.7 & $1,528.1$ & $1,801.4$ \\
Sub-Saharan Africa & 313.1 & 689.6 & 877.4 \\
Central and Eastern Europe and the CIS & 366.6 & 405.3 & 396.8 \\
OECD & 925.7 & $1,164.8$ & $1,233.6$ \\
High Income OECD & 765.9 & 922.6 & 968.5 \\
High Human Development & $1,012.5$ & $1,275.0$ & $1,350.0$ \\
Medium Human Development & $2,743.2$ & $4,433.1$ & $4,995.8$ \\
Low Human Development & 255.0 & 571.7 & 737.1 \\
High Income & 792.3 & 982.5 & $1,040.9$ \\
Middle Income & $2,042.9$ & $3,043.0$ & $3,319.6$ \\
World & $4,073.7$ & $6,389.2$ & $7,219.4$
\end{tabular}

Source: Human Development Report, 2006.

The search for food security is a world-wide concern as it defiles all geographical boundaries. Food insecurity could be found in rich nations as well as poor nations, in the drought free, mid-income and low-income countries as well as $\mathrm{n}$ the food deficit regions of the world (World Bank, 1998). The Millennium Development Goals (MDGs) initiated in 2000 put Eradication of extreme poverty and hunger as its first priority (UNDP, 2006). Poverty is still written in many faces in various countries of the world. Not less than 800 million people still suffer from abject poverty, living on less than $\$ 1 /$ day (FAO, 2008).

The developing countries are still dominating the population stage with 5.1 billion people. The proportion of people living in abject and absolute poverty is increasing and estimated about 1 billion people still go hungry daily. Many people are still found falling below the benchmark $\$ 1$ day feeding rate, most of whom are found in Asia and Pacific, and Sub-Saharan Africa. Table 2 presents the situation of countries with highest and lowest Human Development Index (HDI) in Europe and Africa with a wide margin between them. For example, the leading country of Europe (Iceland) had HDI of 0.968 compared to the lowest in Africa (Sierra Leon)'s HDI of 0.336 appears rather unthinkable. The cause of this human disparity in development might not $b$ unconnected with the apparent food crisis being experienced in many countries. It further shows that there are lots to be done in the context of development and so, appropriate strategies and programmes be applied to close this appalling gap. When details of indices on Life expectancy, adult literacy rate, enrollment ratio for schools, GDP per capita are considered, the countries with low HDI have more work to boost their development statuses (Human Development Report, 2006). For example, Iceland, the leading country in Europe has (0.968) HDI 
compared with the lowest in Africa, Sierra Leone with the figure of (0.336) HDI. What a wide gap existing between the rich and the poor nations!

Amosa (2006) looked at food security trends in Kenya from national, district and household perspectives, contending that adequate food provision involves the use of various strategies, laying emphasis on the people's experiences including social networks and the capacity to manipulate available opportunities.

Table 2: Human Development Indices (HDIs) of ten highest and ten lowest countries in Europe and Africa, 2005.

\begin{tabular}{|c|c|c|c|c|c|}
\hline \multicolumn{3}{|c|}{ Europe 10 highest HDIs } & \multicolumn{3}{|c|}{ Africa 10 lowest HDls } \\
\hline Rank & Country & HDI & Rank & Country & HDI \\
\hline 1 & Iceland & 0.968 & 1 & Sierra Leone & 0.336 \\
\hline 2 & Norway & 0.968 & 2 & Burkina Faso & 0.370 \\
\hline 3 & Ireland & 0.959 & 3 & Guinea Bissau & 0.374 \\
\hline 4 & Sweden & 0.959 & 4 & Niger & 0.374 \\
\hline 5 & Switzerland & 0.955 & 5 & Mali & 0.380 \\
\hline 6 & Netherlands & 0.953 & 6 & Mozambique & 0.384 \\
\hline 7 & France & 0.952 & 7 & Central African Republic & 0.384 \\
\hline 8 & Finland & 0.952 & 8 & Chad & 0.388 \\
\hline 9 & Spain & 0.949 & 9 & Ethiopia & 0.406 \\
\hline 10 & Denmark & 0.949 & 10 & Congo & 0.411 \\
\hline
\end{tabular}

\section{Some Causes of Food Crisis}

Food crisis does not just occur. They were precipitated by remote or immediate causes. Some of the causes are individual-induced, some corporately caused, some societal problems, while others are national and international effects of some inadequacies and deficiencies.

Some of these are worthy of highlighting here.

$>$ Population growth; an increment in the reproduction of humans without corresponding growth in crop production.

$>$ Low food crop production; a low food production unable to match the demand

$>$ Continuous rise in prices; a continuous increase in the prices of food crops leading to low purchasing power.

$>$ War/conflicts and crisis (refugee increase); instabilities and crisis in many parts of the world lead to refugee movement, displacement of work-force and abandonment of many families

$>$ Environmental disasters e.g. floods, desertification, global warming); due to unexpected natural causes.

$>$ Shortage of water supply; many parts of the world experience inadequate supply of water leading to thirst and hunger.

$>$ External debt over-load; due to indebtedness of many underdeveloped and developing countries, they are incapable of making significant progress.

> Over-dependence on donations/aids/grants; many countries still depend on grants and aids from the advanced countries and could not earnest their endowed resources. 
$>$ Biofuel development; the recent trend in generating biofuels from crops is putting stress on demand for energy at the expense of food crops.

Goodman (2008), had given signals of the world-wide food shortage with the following grim information/statistics - including its consequent manifestations viz -aviz;

* Total world stocks of all grains are close to their lowest level in 30 years.

* USDA predicts wheat surpluses to be the smallest in 60 years.

${ }^{*} A$ virulent strain of wheat rust that can reduce yields to zero is spreading worldwide.

* Wheat prices have risen well over 50 percent from a year ago.

* The FAO cites 37 countries as facing a food crisis due to rising prices.

In addition, he quoted Josette Sheeran, Executive Director of the World Food Programme (WFP) as follows;

"Soaring food prices -- up 55 per cent from June 2007 to February 2008, including an 87 per cent hike for rice in March -- and dwindling global food stocks due to more world food consumption than production were seriously threatening the WFP's ability to keep millions from starvation."

Therefore, it is of paramount importance that attention be paid by various Governments of the world to prevent or avert situations that may generate or degenerate into imminent food crisis. It is note-worthy to cultivate the culture from the adage that says; "Prevention is better than cure".

\section{Some Approaches to Solving Food Crisis}

Due to the precarious situation of the global dimension to the food crisis, various approaches have been taken toward its containment. Some of these approaches, in as much as they were genuine and well-intentioned, however, were largely short-termed, localized and temporary.

\section{$>$ Importation}

As a panacea to food crisis and hunger, various countries have had to resort to importation of foodstuff. Of course, this is not without cost as huge finances are expended annually on imports at the detriments of other facilities and opportunities. The good side to this development is that the countries exporting such goods are making good foreign exchange from the business and the proceeds of which they used to take care of their countries' needs.

\section{$>$ Green Revolution}

The term "Green Revolution" was the brain child of a fascinating 1968 lecture by William S. Gaud, then Administrator of AID who came up with this term "It is not a violet Red Revolution like that of the Soviets, nor is it a White Revolution like that of the Shah of Iran. I call it the Green Revolution." (Source: www.agbioworld.org/biotech-info/topics/). The wind of Green revolution has blown through to many countries in Asia and Africa, South America, producing a dramatic change in research, technology and agricultural production, leading to growth.

\section{$>$ Donations}

According to FAO statistics, since 1995 , the whopping sum of US $\$ 770$ million from donors and national governments have been put on FAO initiated food security programmes being carried out in many countries of the world (FAO, 2008). A lot of other food supply projects and initiatives taking billions of US 
Dollars (\$) are being carried out both by Governments and private organizations.

\section{$>$ National Programme for Food Security}

FAO had stressed that: "Food security exists when all people, at all times, have access to sufficient, safe and nutritious food to meet their dietary needs and food preferences for an active and healthy life". FAO had introduced what it called Special Programme for Food Security (SPFS). According to FAO (2008), the following are the distribution of SPFS participating countries in major world regions; Africa (44), Latin America and Caribbean (27), South-West Pacific (14), Asia 13), North-East (5) and Europe (3). (Source: www.Fao.org).

A National Programme for Food Security (NPFS) is a country-driven solution to eradicating hunger within the local population.

FAO achieves this by:

1. supporting national governments in identifying ways to remove barriers to food access;

2. mobilizing donor resources for project funding; and

3. assisting with the kick-off and implementation phases.

While no two National Programmes are alike, their main essential features include:

- strong national commitment; and

- supportive policies and regulations.

- full engagement of civil society;

According to $\mathrm{FAO}$, sustainable food security requires;

- stable supply of adequate food;

- properly functioning markets; and

- that all households are able to generate a combination of home-produced food and cash income sufficient to cover all their basic needs.

According to the FAO's SPFS, it is essential that National Programmes reach the undernourished with activities that enhance their productivity and incomes on a nationwide scale. The large-scale multiplication of locally implemented activities is the only workable option for reaching the entire target population. The National Programme's vision is of village-by-village development on a national scale.

In Nigeria, the Government has introduced (in August, 2002) National Special Programme for Food Security (NSPFS) and had set up project with 109 programme sites located in Senatorial Districts across the nation - with the aim of increasing food production on sustainable basis and improving people's access to food (security) in Nigeria. The first phase has been adjudged to be a success, and so, the Government has embarked on a wider coverage by introducing the second phase. NSPF is a joint project between the Federal Ministry of Agriculture and Rural Development (FMARD) and the Food and Agriculture Organization (FAO) of the United Nations (UN).

\section{> Millennium Development Goals (MDGs)}

As earlier pointed out, the MDGs is principally aimed at eradicating poverty in all its ramifications. Hence, many countries (about 200 of them) of the world who consented to the goals have had to embark on projects and programmes designed to reduce poverty.

According to United Nations (2008), from the MDGs report (2008), a half-way assessment of the MDGs target date (2015), some key successes achieved were; 
- more access to safe drinking water to estimated 1.6 billion people

- The central goal of reducing absolute poverty by half is within reach for the world

- In all but two regions, primary school enrollment is at least $90 \%$.

- The gender parity index in primary education is $95 \%$ or higher in six of the 10 regions

- Deaths from measles fell, vaccinations on it are available to $80 \%$ of children in developing countries, malaria prevention is expanding, incidence of tuberculosis is expected to stop and begin to decline

- The use of ozone-depleting substances has been almost eliminated, reducing global warming

- The developing countries share of export earnings devoted to debt servicing fell from $12.5 \%$ (2000) to $6.6 \%$ (2006), giving them more resources allocation.

While this record looks impressive, the battle for the development of the world in alleviating her from the clutches of poverty is far from over. We should not deceive ourselves.

\section{Examples of Regions/Countries Experiencing Food Crisis}

FAO (2008) reports indicated not less than 37 countries are facing a food crisis of one proportion or the other due apparently to rising prices. Friends of the World Food Program (2008) reported food problems being experienced in many countries/regions of the world. Some are notable here;

\section{Africa}

- In Guinea Bissau, the price of imported rice has escalated over October, 2007 level by $25 \%$. A survey indicated that about $14 \%$ of rural households are either moderately or severely food insecure.

- In Mauritania, a country that imports $70 \%$ of its food need, due to high prices of basic commodities, is facing pressure on the people's purchasing power. It is estimated that additional $\$ 183$ million food aid is required for the country.

- In Somalia, in early 2008 , the prices of sorghum and imported rice almost doubled due to rise in global fuel prices.

- In Egypt, for example, as a result of the unfortunate food problem, people had to resort into taking food with low nutritional value, cutting down on expenses on education and health thereby causing protests of the people. In reaction, the Egyptian Government had to increase its subsidies to the poor amounting to $\$ 4$ billion.

\section{Middle East}

- A report from FAO had indicated that the Middle East may likely suffer losses from environmental problems like soil degradation, droughts, high temperatures and floods.

- In 2008, World Food Program (WFP) provided nearly 4 million people living in Iraq, Yemen, Syria, Egypt and Palestinian territory with some food assistance.

- In Iraq, due to displacement of about 750,000 people, WFP requested for $\$ 87.5$ million assistance on food and additional $\$ 9$ million is expected due to rise in food and fuel prices. 


\section{Latin America/Caribbean}

- A USDA study had alleged that due to food price increments, Latin America may be most affected. For example, Haiti had its share of riots in April, 2008 with reported deaths. In response, the Government pronounced a $\$ 10$ million booster package on cost of living. Also, an estimated \$96 million relief on food by WFP was expected to help Haiti people.

- In Nicaragua and Elsalvador, due to rise in food prices, people's purchasing power had dwindle and their nutritional intake and diet are being adversely affected. The situation was not different from Guatemala.

\section{Asia}

- In Tajikistan, wheat prices have increased by $128 \%$ and flour prices by $76 \%$, and vegetable oil by $126 \%$ within a year. The Government had to seek for assistance for fuel and food. In Bangladesh, it was estimated that in 2007, the price of rice rose by $70 \%$. For Afghanistan, 2.5 million people were estimated to be hungry in early 2008 and the President had to appeal for $\$ 77$ million assistance.

- Cambodian escalating food prices has had untold repercussion on school feeding programme and estimated 450,000 children beneficiaries could be affected. In Indonesia, due to price increase on commodity, causing unrest, the Government had to scale up its rice subsidy programme by $50 \%$ and was considering extending it to cover about 80 million people.

According to CTA (2008), some policy measures have been advanced toward ameliorating the spate of food insecurity being experienced in many countries.

\section{Lessons for Nigeria and Way Forward}

Ladele (2005) had contended that national development is not a matter of chance but deliberate planning guided through combined policies, plans and strategies. The world's global recession and food crisis portends a lot of graphic lessons for Nigerian economy. Interestingly enough, the global financial crisis of 2008 did not adversely affect Nigeria or was not significantly reflected in her economy like other countries, except for the fluctuation in oil prices.

$>$ Agriculture has been contributing largely to the GDPs of Nigeria before and after independence (1960). From 1970 to 1990s, however, the trend changed as the oil boom era took over the stage. Successive Governments have had to introduce intervention/programmes/projects aimed at restoring agricultural production and productivity. Also, from time to time, successive Governments had banned and unbanned importation of some essential foodstuff depending on the need and policy framework (Shuaibu, 1997). For example, the scandal that surrounded the rice importation during the defunct Shagari Administration (1979-1983) provides a classic illustration. In addition, and of recent, in early 2008, when the food crisis phenomenon and fear gripped many countries of the world, a bag of $50 \mathrm{Kg}$ of rice suddenly increased from $\$ 5,000.00$ to A12,000.00. The tension was high and everyone, including the Government, was apprehensive and importation was a high point of consideration as option.

$>$ For some years now, Nigeria has pride herself of having strategic grain reserves (SGRs) in various locations across the nation. Essentially, these reserves were meant to serve the people in terms of food supply at the 
moderate prices. Unfortunately, due to the so-called "Nigerian factor", the control of the reserves is faced with constraints of wrong forecasts/planning, political influence, uncoordinated distribution mechanisms.

> Nigeria has been realizing increase in revenue from oil (petroleum). Unfortunately, the nation has not been having enough of the gains in spite of huge and ever-increasing national annual budgets. A case in point is the 2008 national budget which the Government has been criticized by the Legislature for lack of full implementation. The country's huge foreign exchange earnings should have been expended on critical areas like agriculture, health, education, and industrialization.

$>$ For the fact that Nigeria has not had serious and adverse effect of food crisis like in some other arts of the world does not mean it might not and will not. It only gives us a signal that we should avoid it and prevent it if we can. Where others have fail we should succeed. Where others have lacked we should have.

> Nigeria's debt portfolio have decreased largely due to the debt forgiveness of 2006. The Government, under no guise or pretension should not yield to temptation of taking just any debt without taking thorough consideration. It should be avoided like a plague.

$>$ The people and Government of Nigeria should focus more in realizing rural and agricultural development. Since the larger proportion of the population is found in the rural enclave, the better that development in all ramifications be centred on them. It is when the rural areas are developed that we can all boast of development.

$>$ It has been shown that Agriculture contributed $41.73 \%$ to the Nations GDP in 2006 and $42.01 \%$ in 2007 (National Bureau of Statistics, 2008). This statistics could be improved upon in such a way that the agriculture will play a meaningful dominant role in the nation's economy.

$>$ Smuggling of goods (including crops and especially food crops) across the Nigerian porous borders should be checked in order to give the country and its people adequate food. The danger in consuming foodstuff smuggled across the borders has with it an untold hardship and risk.

\section{Conclusion}

The story of the food crisis/food insufficiency being experienced in many parts of the world calls for concern by both leaders and followers of the world. The fact that the so-called advanced countries are relatively comfortable does not mean it will be so for eternity. Those who are hungry today should not loose hope nor be despondent. These are hard lessons of life for all. Nigeria is well positioned to avert the gloomy food crisis if all her resources are well utilized and properly directed. Let no one be under illusion - food could be scarce and expensive any day. We must work towards preventing its occurrence. A well-packaged compendium of Government policies on food insecurity, poverty, energy diversion, biofuels, resource use, underdevelopment and stagnation of economy, debt management - all will be a step in the right direction. 


\section{References}

Amosa, M. (2006). Food Security Trends: A Situation Analysis of Food Supply Differentials in Rural Kenya. IDS Discussion Paper No.300. Pp55.

CTA (2008). Policy Responses to food crisis. In: AGRITRADE- A publication of CTA. June Edition. Accessed online at : www.cta.org/

Food and Agricultural Organization (FAO) (2005). Food Production Index Number. FAO Statistics Division. Accessed online at : www.fao.org/foodproductionindexNumbers en.

Food and Agricultural Organization (FAO) (2008). Food insecurity Assessment Report. (Accessed online at: www.Fao.org)

Friends of the World Food Program (2008). Global Hunger Crisis. Available at: www.friendsofwfp.org/.

Goodman, J. (2008). "Food Shortage Looming if Crop Focus Isn't Altered", (Available at: www.OpEd.com/).

Jibowo, A. A. (2000). Essentials of Rural Sociology (Second Impression). 'Gbemi Sodipo Press Ltd., Abeokuta, Nigeria. Pp244.

Ladele, A. A. (2005) Rural Development Process and Practice. In: Ed. Prof. S. Fola Adedoyin: Agricultural Extension in Nigeria. A Publication of Agricultural Extension Society of Nigeria (AESON). P139-144.

National Bureau of Statistics, Federal Republic of Nigeria (2007). Statistics on Nigeria. Available online at: www.nigerianstat.gov.ng/

Shaibu, B., Aliyu A. and Bakshi J. S. (1997). Nigeria: National Agricultural Research Strategy Plan 1996-2010. Compiled and edited by B. Shaibu, A. Aliyu and J.

S. Bakshi: Department of Agricultural Sciences, FMA\&NR, Abuja, Nigeria.Pp.335.

World Bank (1988). The Challenge of Hunger in Africa. A publication of World Bank . Washington, D. C., U. S. A.

United Nations (2008). The Millennium Development Goals Report 2008. United Nations, New York. Pp52.

United Nations Development Programme (UNDP) (2006). United Nations Development Programme Report, 2006.

Websites consulted:

www.cta.org

www.undp.org

www.fao.org

www.friendsofwfp.org/site/

www.nationmaster.com/country/ni-nigeria/agr-agriculture

www.fao.org/ES/ess/index en.asp

www.nigerianstat.gov.ng/

www.agbioworld.org/biotech-info/topics/).

www.en.wikipedia.org/wiki/Food security/

http://europa.eu/rapid/pressReleasesAction.do?reference=IP/08/763\&format=HTML

\&aged=0 \&language $=E N \&$ guilanguage $=e n$

EC communication on tackling the challenge of rising food prices, COM (2008) 321

final, Brussels, May $20^{\text {th }} 2008$

http://ec.europa.eu/commission_barroso/president/pdf/20080521_document_en.pdf

EC staff working paper on issues faced with regard to high food prices, Brussels $D(2008)$, May $6^{\text {th }} 2008$

http://ec.europa.eu/agriculture/analysis/tradepol/foodprices_en.pdf 
EC note to the file on recent price developments in EU27 agricultural and food retail, CMD (2008), Brussels, April 8th 2008

http://ec.europa.eu/agriculture/analysis/markets/food05_2008_en.pdf

World Bank analysis of the implications of higher global food prices for poverty in low-income countries, WPS4594, April 2008 